\title{
The role of land-use visions for protection of forest landscapes: the Białowieża Forest (Poland)
}

\author{
El rol de las visiones del uso del suelo en la protección de los paisajes forestales: el bosque de \\ Bialowieza (Polonia)
}

\section{Barbara Bożętka}

Gdańsk University, 4 J. Bażyńskiego Street, 80-952 Gdańsk, Poland, geobb@univ.gda.pl

\begin{abstract}
SUMMARY
The work concentrated on relations between the issues of use and protection that developed in the Polish part of the Białowieża Forest last century, particularly during the post-war decades. Owing to extraordinary natural values, the area deserves very careful protection, however, negative impacts on the landscape have been widely observed. The changes involving perforation and fragmentation of forest cover caused by continuous logging are accompanied by spatial disorder in built areas and their vicinities resulting from tourism development. The aim of the research was to identify the underlying forces of negative tendencies and simultaneously, obstacles to progress in nature conservation of the area. Comparison of views and visions of land-use and management of the Forest showed that great differences in attitudes, applied perspectives and expectations to the Białowieża Forest exist. The study revealed the importance of a socio-cultural dimension for a current stage of landscape evolution. This influence is connected with a steady pressure on wood exploitation and results, at least partially, from a strong position of forest administration in this area and from specific land-use visions emphasizing economic services of the forest. Noteworthy, actions undertaken across the country and numerous efforts to extend protection of the area have not succeeded so far. It is argued that underestimation of natural values expressed by local communities in addition to weaknesses of the state's environmental law may bring serious hazards to the analysed landscape and affect the whole system of nature conservation in Poland.
\end{abstract}

Key words: landscape, change, values, Białowieża Forest, Poland.

\section{RESUMEN}

Esta investigación estudió las relaciones entre el uso y protección del bosque Białowieża, Polonia, durante el último siglo, particularmente en las décadas de la post-guerra. Debido a los extraordinarios valores naturales, esta área necesita una protección muy especial. Sin embargo, se han observado diversos impactos negativos sobre el paisaje. Los cambios implicaron perforación y fragmentación del bosque causados por la continua tala de árboles, debido a la expansión urbana asociada al desarrollo turístico. El objetivo de esta investigación fue identificar los forzantes subyacentes de tendencia negativa y los obstáculos para el progreso de la conservación de la naturaleza en la zona. Comparación de puntos de vista, visiones de uso del suelo y manejo del bosque, evidenciaron importantes diferencias en actitudes, perspectivas y expectativas aplicadas al bosque de Białowieża. El estudio reveló la importancia de la dimensión socio-cultural en el estado actual de evolución del paisaje. Esta influencia está relacionada con una presión constante sobre la explotación maderera, por lo menos parcialmente, desde una fuerte posición de la administración forestal en esta área y desde visiones específicas de uso de suelo que enfatizan los servicios económicos de los bosques. Cabe destacar, que acciones realizadas en todo el país y los numerosos esfuerzos para ampliar las áreas de protección no han tenido éxito hasta el momento. Se argumenta que la subestimación de los valores naturales expresada por las comunidades locales, además de las debilidades de la legislación ambiental del Estado, pueden traer serias amenazas para el paisaje analizado y afectar a todo el sistema de conservación de la naturaleza en Polonia.

Palabras clave: paisaje, cambio, valores, bosque Białowieża, Polonia.

\section{INTRODUCTION}

The Białowieża Forest is a remnant of vast European lowland woodlands and it still exhibits several features indicating a rich primeval forest. Possessing outstanding natural values, the area was enlisted to Unesco World Heritage in 1979. However, recent centuries (Mitchell and Cole 1998) and particularly, the $20^{\text {th }}$ century has been con- nected with acceleration of disturbance processes (Conservation of the Białowieża Forest 2003, Wesołowski 2005). A current study regards processes that affected the Polish part of the Forest during last decades.

The work consists of three parts. The first part is focused on landscape change and identifies main tendencies characteristic of the post-war period. The second aims to distinguish the underlying forces of change. The third part 
is concentrated on current visions of the Białowieża Forest and its land-use, and consequently, on conceptions of its management and preservation. Trying to recognize the logic of the forest's management the study exposes different attitudes to the Forest as well as levels and agents of social interactions.

\section{METHODS}

The Białowieża Forest (Puszcza Białowieska) is situated in the north- eastern part of Poland, near the present Polish- Byelorussian border (figure 1). The Forest stretches over 150,000 ha (62,500 ha in Poland) and is a constituent of a unique landscape formed by the most extensive stands of old-growth woodlands in Europe. It lies in the transition between the boreal and temperate zones, is composed of diverse plant communities, e.g. oak-lime hornbeam (Tilio-Carpinetum Oberd) and pine-spruce-oak (Pino-Quercetum Ilicis, Faliński 1986, 1988, Kwiatkowski 1994) and comprises extensive marshy land. This is a refuge for numerous protected and endangered species, for instance the European bison (Bison bonasus Linnaeus), wolf (Canis lupus Linneo), lynx (Lynx lynx Schreber), golden eagle (Aquila chrysaetos Linnaeus), snake eagle

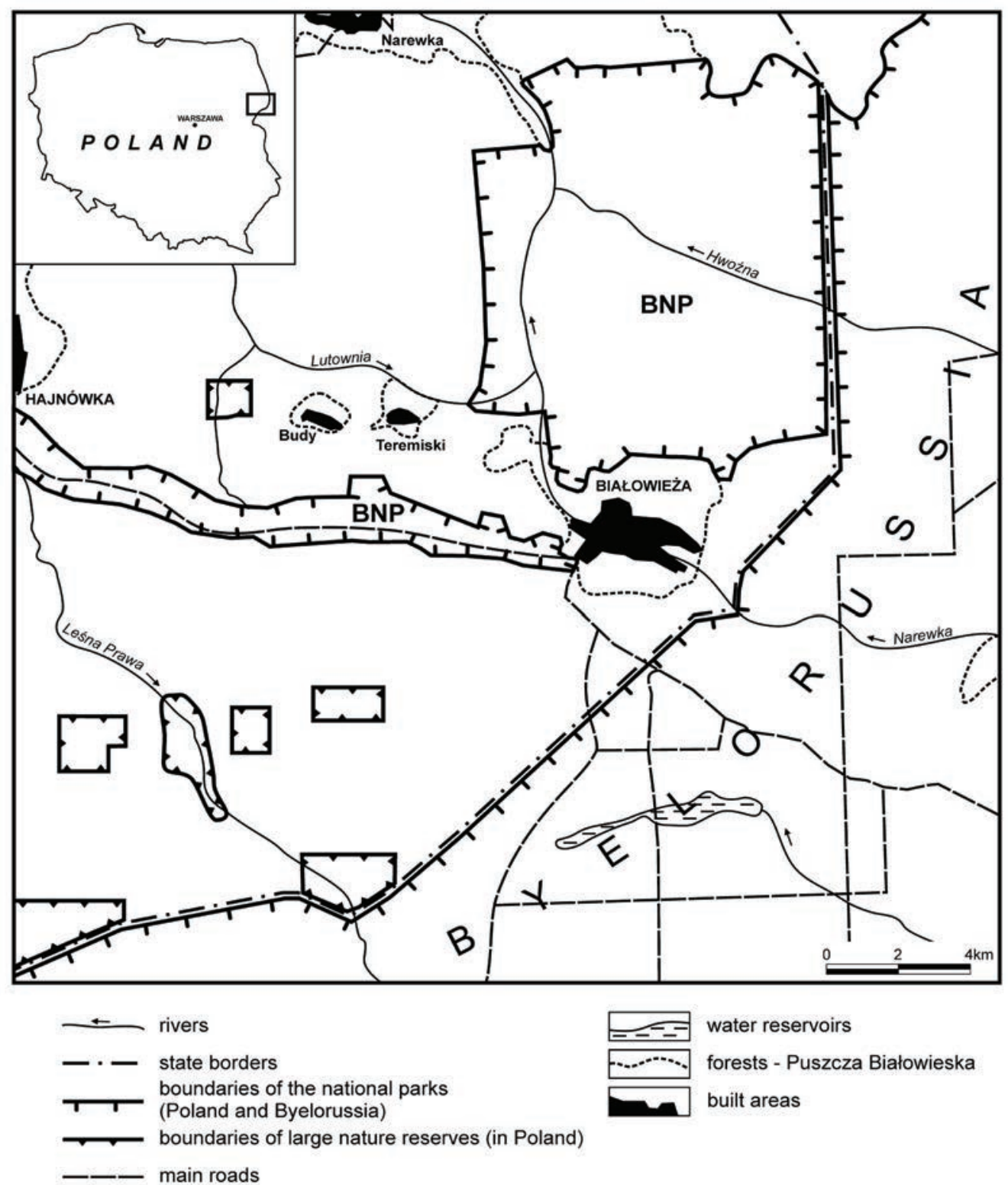

Figure 1. The Białowieża Forest- a central part (on the basis of 1:200,000 Topographic maps N-34-XXX, N-34-XXXVI, 1992, Wojskowe Zakłady Topograficzne, Warsaw).

Parte central del bosque de Bialowieza (Con base en mapas topográficos N-34 XXX, N-34-XXXVI, 1992, escala 1: 200.000, Wojskowe Zakłady Topograficzne, Varsovia). 
(Circaetus gallicus Gmelin), great grey owl (Strix nebulosa Forster). Remarkably, socio-cultural elements of the landscape have always been strongly dependent on forest amenities. The region is highly ranked in conservation system; several forms of protection can be found here, including National Park, a Biosphere Reserve, and an Important Bird Area. However, it is widely reported that existing protection is insufficient (Conservation of the Białowieża Forest 2003, Wesołowski 2005). While a part of the forest is managed as a strict reserve (Białowieski National Park), the rest has been facing a steady human impact.

A preliminary stage of the study was focused on a broad-scale landscape analysis and comprised an extensive research of literature with contribution of comparative studies of geobotanic and topographic maps, satellite photos and statistical data. The second phase comprised the synthesis of the results and aimed to distinguish main processes of landscape change. The subsequent conclusions revealed significance of anthropogenic factors for the present state of the landscape. Therefore the third stage put stress on socio-cultural determinants of identified processes and emphasized concerns connected with attitudes to the forest, views and visions of landscape use and values exhibited by different social groups. Observation and a wide analysis of relevant literature including not only scientific reports, but also additional materials such as interviews and press articles were all important for this stage of the study. Furthermore, the research incorporated examination of state and regional environmental policy, management plans (Forest Management and Inventory Plans ${ }^{1}$ ), adequate planning procedures (including spatial plans and policies of local communities), and an array of other official documents (formal letters among interested groups and administrative decisions).

\section{RESULTS}

An analysis of landscape change showed that a considerable human impact on the Polish part of Forest began during the $1^{\text {st }}$ World War (1915) and consisted in largescale logging operations. In 1990s exploitation rates, though not performing as the highest in history, tended to increase above a level of $130,000 \mathrm{~m}^{3} \mathrm{yr}^{-1}$ (Wesołowski 2005, Forest Management and Inventory Plans 2001$2011^{1}$ ). In consequence, significant changes of landscape structure appeared, which are connected with the process of borealisation, appearance of new habitats, rejuvenation, reduction of an amount of dead wood, and unification of spatial structure (Bobiec et al. 2000, Fuller 2000, Conservation of the Białowieża Forest 2003, Wesołowski 2005). It is proved that many key bird species are much scarcer

\footnotetext{
Forest Management and Inventory Plans 2001-2011: Białowieża, Browsk, Hajnówka. Regionalna Dyrekcja Lasów Państwowych w Białymstoku. Białystok. 2003

Forest Management and Inventory Plans 2012-2021: Białowieża, Browsk, Hajnówka. Regionalna Dyrekcja Lasów Państwowych w Białymstoku. Białystok 2011.
}

in logged fragments than in protected zones (Czeszczewik and Walankiewicz 2006, Wesołowski et al. 2005). Cutting has been continuing until now, exceeding the amount of 1,100,000 $\mathrm{m}^{3}$ in the period 2002-2011 (Forest Management and Inventory Plans 2012-2021: Białowieża, Browsk, Hajnówka; Management and Protection Program $2011^{1}$ ) and became a cardinal, but not a single factor leading to deterioration in landscape structure. Regarding general spatial processes in land transformation (Forman 2006) the role of perforation and fragmentation of a forest cover should be highlighted. Additionally, investigation of spatial documents of the local communities ${ }^{2}$ revealed that settlement sprawl, which frequently accompanies tourism and leisure, induces spatial disorder in major villages and their vicinities and considerably adds to degradation caused by wood exploitation.

The undertaken research showed that two predominant, contrasting land-use visions of the Białowieża Forest play a significant role in discussion on and establishment of management plans and environmental policy of the area. Forest authorities supported by local societies and local authorities insist on the necessity of wood production, and on the other hand, bodies engaged in nature conservation in Poland, e.g. non-government organisation highly promote strengthening of ecological functions. Additionally, an option linking wood extraction with new forms of landscape protection has developed as an antagonistic idea towards the park's extension. Noteworthy, a crucial issue consists in reasoning of the models of development. The analysis showed that two of the possibilities go along with steady socioeconomic pressure on intensification of logging. Thus, it can be argued that a simplistic, well-established vision of forest and its management can be seen as a prominent driver of landscape change.

The research revealed significant differences in patterns of perception of the Białowieża Forest. This is interesting that characteristic stress put on exploitation, which is expressed by local communities (Giergiczny 2009) does not find appreciation in the country (Czajkowski et al. 2008). Disturbing changes and their consequences provoked a lengthy debate on management and protection of the Białowieża Forest (Kozieł 2010). Moreover, an important difficulty faced by the Forest is caused by weaknesses of the state's environmental legacy- a decisive role of local communities in the process of establishing and changing national parks made enlargement of the Białowieża National Park impossible. Therefore a question on values attached to the landscape and attitudes both to the Forest and to nature conservation carries a lot of weight. Numerous press articles, leaflets, as well as formal decisions ${ }^{3}$

\footnotetext{
2 Study of the spatial plan of the Białowieża community. 1999, with changes. Białowieża.

Study of the spatial plan of the Hajnówka community. 2008. Biała Podlaska. Study of the spatial plan of the Narewka community. 2010. Narewka.

3 Conservation of the Białowieża Forest (Poland), Document for information for the Bureau. 2003.
} 
and specialist publications (Wesołowski 2005) examined in this work signal a considerable influence of forest authorities, responsible for management of areas outside the National Park, on the social awareness. As a result, public opinion on a local level underestimates importance of natural values contrary to economic services provided by the Forest. Against numerous country and international attempts to change the paradigm of forest management, an emphasis is still laid on elementary benefits and on a need to retain control over the natural processes (Management and Protection Program ${ }^{4}$ ). Employment of these visions in landscape management, though may meet expectations of certain groups of interest, will result in serious decline in ecological values and in landscape depreciation. A further loss of oldest tree stands is one of the consequences (Wesołowski 2005). It should also be stressed that deterioration in landscape structure is connected with a problem of low respect for aesthetic values encapsulated in the ancient forest (Korbel 2012).

\section{DISCUSSION AND CONCLUSIONS}

An analysis of contemporary factors and processes of change taking place in the area of the Białowieża Forest has demonstrated that the region has been threatened by a decline in its intrinsic natural qualities (see e.g. Mitchell and Cole 1998, Bobiec et al. 2000, Conservation of the Białowieża Forest 2003, Wesołowski 2005, Kozieł 2010). One of the most important forms of deterioration in landscape structure consists in habitat fragmentation and is caused mainly by exploitation of the area for commercial forestry (Mitchell and Cole 1998, Bobiec et al. 2000, Fuller 2000, Wesołowski et al. 2005, Czeszczewik and Walankiewicz 2006). As outlined before, land-use visions deserve special attention, since they can become an essential factor of landscape change. Results of the research lead to two general conclusions: 1. Relations between human and natural are essential as far as effective conservation of the forest is regarded, 2. Maintenance of extraordinary values of the area requires the change of social attitude to the Forest (especially at a local level).

Nowadays the Białowieża Forest is at its turning point; the parliament is working on the change of the State's Nature Protection Law (Ustawa o ochronie przyrody 2004). A direction of landscape evolution depends on decisions being taken with consideration to ecological and socioeconomic conditions and on hierarchy of values attached to forest and more, to nature amenities. Noteworthy, it can be argued that a specific attitude of local communities and local authorities highlighting productive functions of the primeval forest and tending to dismiss concerns of conservation and national heritage (Conservation of the Białowieża Forest 2003, Wesołowski 2005, Korbel 2012) constituted not only a strong driving force of landscape

\footnotetext{
4 Management and Protection Program for LKP 'Białowieża Forest' 2012-2021.
} Regionalna Dyrekcja Lasów Państwowych w Białymstoku. Białystok, 2011. change at a regional level, but also one of narratives of nature conservation in Poland.

It seems to be important that an analysis of processes instigating a post-war degradation of the Białowieża Forest must be followed by a discussion on social perception of natural values and services forest ecosystems provide. They constitute a basis for land-use visions and become a hidden factor highly influencing nature conservation and landscape change.

\section{REFERENCES}

Bobiec A, H van der Burgt, K Meijer, C Zuyderduyn, J Haga, B Vlaanderen. 2000. Rich deciduous forests in Białowieża as a dynamic mosaic of developmental phases: premises for nature conservation and restoration management. Forest Ecology and Management 130: 159-175.

Conservation of the Białowieża Forest. 2003. Convention on the Conservation of European Wildlife and Natural Habitats. Standing Committee 23rd Meeting. Strasbourg, France. T-PVS/Files. 3.13 p.

Czajkowski M, M Buszko-Briggs, N Hanley. 2008. Valuing changes in forest biodiversity. Stirling Economics Discussion Paper 2008-17: 1-27.

Czeszczewik D, W Walankiewicz. 2006. Logging affects the White-backed Woodpecker dendrocopos leucotos distribution in the Białowieża Forest. Annales Zoologici Fennici 43: 221-227.

Faliński JB. 1986. Vegetation dynamics in temperate lowland primeval forests. Ecological studies in Białowieża Forest. Dordrecht, The Netherlands. Dr W. Junk. 537 p.

Faliński JB. 1988. Succession, regeneration and fluctuations in the Białowieża Forest (NE Poland). Vegetatio 77: 115128.

Forman RT. 2006. Land mosaics. The ecology of landscapes and regions. Cambridge, UK. Cambridge University Press. $632 \mathrm{p}$.

Fuller RJ. 2000. Influence of treefall gaps on distribution of breeding birds within interior old-growth stands in Białowieża Forest, Poland. The Condor 102: 267-274.

Giergiczny M. 2009. Rekreacyjna wartość Białowieskiego Parku Narodowego. Ekonomia i Środowisko 2 (36): 116-128.

Korbel J. 2012. Malarz Puszczy Białowieskiej. Dzikie Życie 4 (2012): 22-23.

Kozieł M. 2010. Ochrona walorów przyrodniczo-krajobrazowych na pograniczu polsko- białoruskim na przykładzie Puszczy Białowieskiej. Problems of Landscape Ecology (26): 271-284.

Kwiatkowski W. 1994. Krajobrazy roślinne Puszczy Białowieskiej. Phytocoenosis, 6, Supp. Geobotanical Cartography 6: 35-87.

Mitchell FJ, E Cole. 1998. Reconstruction of long-term successional dynamics of temperate woodland in Białowieża Forest, Poland. Journal of Ecology (86): 1042-1059.

Ustawa o ochronie przyrody. 2004. Dziennik Ustaw RP 2009, n ${ }^{\circ}$ 151. 1220 p. (The State's Law of Nature Protection, dated 16.04.2004).

Wesołowski T. 2005. Virtual conservation: How the European Union is turning a blind eye to its vanishing primeval forests. Conservation Biology 19(5): 1349-1358. 
Wesołowski T, D Czeszczewik, P Rowiński. 2005. Effects of forest management on Three-toed Woodpecker Picoides tri- dactylus distribution in the Białowieża Forest (NE Poland): conservation implications. Acta Ornithologica 40(1): 53-60.

Recibido: 24.05 .12

Aceptado: 10.10 .12 